\title{
STRATEGIES TO INCREASE THE ACOUSTICAL QUALITY OF THE MOSQUES WITHOUT REINFORCEMENT SYSTEM
}

\author{
Ernaning Setiyowati
}

\author{
Jurusan Teknik Arsitektur, Fakultas Sains dan Teknologi, UIN \\ Maulana Malik Ibrahim Malang, Indonesia \\ e-mail: ninkarch99@yahoo.com
}

\begin{abstract}
One of the criteria of a good mosque is a good quality of building acoustic for some ibadah purposes, such as prayer and Friday speech. Mosques with medium size actually need no reinforcement system yet. Unfortunately, most of Indonesian mosques' typological form were given very little attention about their acoustical problem. Such problems have found in almost every mosques. Therefore, some strategies are needed to fix the problem. Those strategies can be practiced on mosque's interior surfaces such as ceiling, walls, and floor. One of the strategy is using the absorption material on the wall and the floor, beside using the reflection material on the ceiling. The placement of those materials depends on the path of the sound. The strategy can be used in every form of mosque with only little different treatment in each mosque's form. With this strategy, it is expected that mosques with medium size will no longer use the reinforcement system, yet the voice still can reach all of the jamaah. Thus this strategy can be used to reduce the use of energy in these buildings.
\end{abstract}

Keywords: Sound, mosque architectural form, acoustic

\begin{abstract}
Abstrak
Masjid yang baik adalah masjid yang memiliki kualitas akustik yang baik. Masjid-masjid dengan ukuran yang sedang sepatutnya belum membutuhkan sistem penguat tambahan. Walaupun demikian, tipologi bentuk arsitektural masjid di Indonesia tampaknya belum memperhatikan permasalahan-permasalahan akustik yang terjadi. Permasalahan-permasalahan akustik terjadi di hampir setiap masjid. Karenanya, dibutuhkan strategistrategi tertentu untuk memperbaiki permasalahan tersebut. Strategi-strategi itu dapat diaplikasikan pada permukaan-permukaan interior masjid, seperti plafon, dinding, dan lantai. Salah satu strategi yang dapat digunakan adalah menggunakan material-material penyerap suara pada dinding dan lantai, serta menggunakan material pemantul pada plafon. Penempatan material-material tersebut tergantung pada jalur yang dilewati oleh suara. Strategi ini dapat diaplikasikan pada setiap bentuk masjid, namun dengan perlakuan yang berbeda pada masing-masing masjid. Dengan strategi ini, diharapkan masjid-masjid berukuran sedang tidak akan membutuhkan sistem penguat untuk menjadikan suara mampu mencapai setiap jamaah di dalam ruang, sehingga bangunan masjid yang bersangkutan dapat menghemat penggunaan energi.
\end{abstract}

Kata kunci: Suara, bentuk arsitektural masjid, akustik

\section{Introduction: The Condition of Mosques and Their Acoustics in Indonesia}

Mosque is the most important building for Moslem society, because it's a place for them to do many islamic activities. Most of the activities need the clarity of sound, like jamaah daily prayers dan Friday speech. Those can be done well if only the mosque have a good quality of acoustic. On the first scrutiny that have been done before, a lot of mosque nowadays has less attention in the acoustical problem. Many of them have reverberation problem and bad sound distribution. This may cause the different clarity level of imam's voice to people who sits in the different area of the mosque. This problem could happen whether in a big mosque with reinforcement system or in a small mosque without one. Moreover, in mosques without reinforcement system, the form of the mosque should have a big influence in the path of the sound.

There are some form's typology of mosques in Indonesia ${ }^{1}$, which are:

a. Square plan

b. Rectangle plan with the long side of wall parallel to kiblah

c. Rectangle plan with the long side of wall perpendicular to kiblah

d. Flat and dome roof

e. Combination of crown and dome roof

f. Development roof form: crown and dome or mixture between them

g. 'Javanese vernacular' form

Roof shape mentioned above is not always similar with the ceiling shape. In some cases, the ceiling shape follows the roof shape, while others have a different shape. 
There are similarities from some typology of mosques' form mentioned above. First is that there is a place for imam in the kibla side. Second is that there are lots of opening at every side of walls, except at the kibla side. These openings are a compliance to tropical climate, because those mosques use a natural ventilation. The area of the opening is different in every mosques. It depends on the necessity of ventilation of the mosque. From Faqih's research objects, the opening area of mosques can be divided into three classifications, which are $<15 \%, 15-45 \%$, and $>45 \%^{2}$.

The main objective of planning mosque's acoustic is the clarity of imam's voice. In order to comply with the purpose of a mosque as a speech room, a room with a good quality of acoustic is needed so the sound can be well distributed to the whole jamaah. One architectural factor that has an influence to the acoustic quality of a mosque is the interior form of haram (main prayer room), which are (1) plan form, and (2) ceiling form.

The surface of a room influences the path of a sound in an enclosed room, whether it is flat, concave, or convex. In a speech room, the placement of these shapes should be arranged well to direct sound to the specific place. In a sound's dispersal, the convex shape is the most suitable shape to be used. So, this kind of shape should occur in some of interior elements of a speech room. It is useful in reflecting and distributing sound, but its placement should also be considered, because a random placement may cause an echo problem.

A room can be considered as having a good acoustic quality if the sound inside could be easily arranged well. The closed room is often considered as a good one because it can isolate noise from outside. Besides, the sound inside could be easily arranged without any fear of losing it. In a wide open room which has no boundary, the path of sound would be different. It would be defracted outside the room ${ }^{3}$. There is a specific distance that could be reached by a sound to be heard. Therefore, a reinforcement system is needed in a building which has a volume more than the ability of a sound to be heard, so that the sound could reach the listener. It is up until about $300 \mathrm{~m}^{3}$ room volume, a single voice can be heard without difficulty and without any special treatment of room surfaces ${ }^{4}$.

A mosque needs a good sound distribution. That is why the arrangement of the interior element should be noticed. From the mosque typology above can be noticed that most mosques have a flat shape of walls. Meanwhile, the convex shape which has a good ability in distributing sound is seldom found ${ }^{5}$. Those shapes are also not well-arranged. It may cause the sound not well-distributed to the whole room. Moreover, the excessive reflection from that shapes might also cause reverberations and echos.
The area of the room also influence the path of sound inside the room, because it has a limited ability which would weakened and lost in a spesific distance. A wide room always needs reinforcement system, but the medium room with less than $300 \mathrm{~m}^{3}$ volume does not need one ${ }^{6}$. Therefore, the medium mosque room around $15 \times 15$ square meter ${ }^{7}$ should not need any reinforcement nor the special acoustic room treatment.

Most of mosques in Indonesia are using reinforcement systems even if some of them considered as small ones. It means that the sound distribution in those mosques is not good enough. Thus some special strategies are needed in designing a good mosque with a good acoustic quality without sound reinforcement system.

This study is a continuing research from the previous one. The previous research's methods are simulation and field measurements. The field measurement has been done in three samples of mosques. The result of these field measurement was put into a computer program to find a better value of Reverberation Time (RT). Some modifications have been done to find the better value of RT, such as changing the material, adding the wall elements, etc. These modifications were used to determine some strategies to create a better acoustic quality of the mosques in this research.

\section{The Value of Tropical Mosques' Room Acoustic Quality}

To increase the acoustic quality of a mosque in the tropical area, the field mesurement should be done first to recognize the real value. The measurement has been done in Masjid Al-Maghfirah, Masjid Nurul Iman, and Masjid Baitussalam as samples for this research. The mosques are all in the housing areas with the same level of noise.

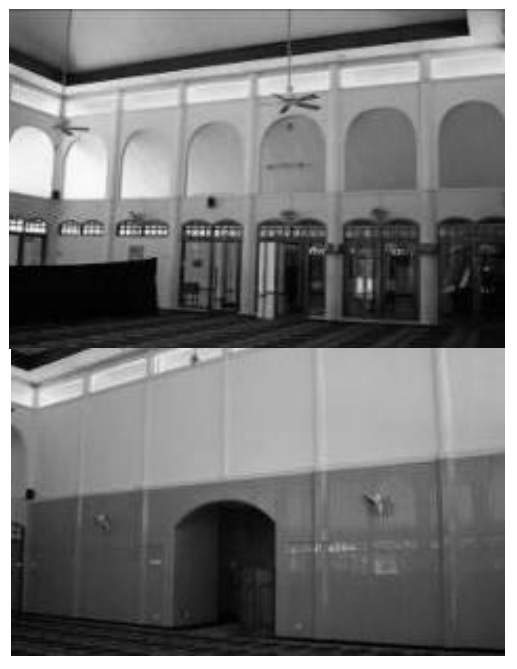

Figure 1. Masjid Al-Maghfirah's Interior 
Masjid Al-Maghfirah is located at Rungkut Asri Estate Surabaya. This building is surrounded by residential buildings, except the south side that is exactly next to the road. This side is the highest noise source for the building. The plan shape is square (Figure $1-2$ ), while the ceiling shape is crown. The mosque's dimension is $14,5 \times 14,5 \times 8$ $\mathrm{m}^{3}$. The composition of materials in this mosque are some reflection materials, which are glass window, glass door, brick plester wall, and ceramic tile on wall. All area of the floor is covered by carpet. The area of opening is $23 \%$ of wall area, which could decrease the reflecting area.

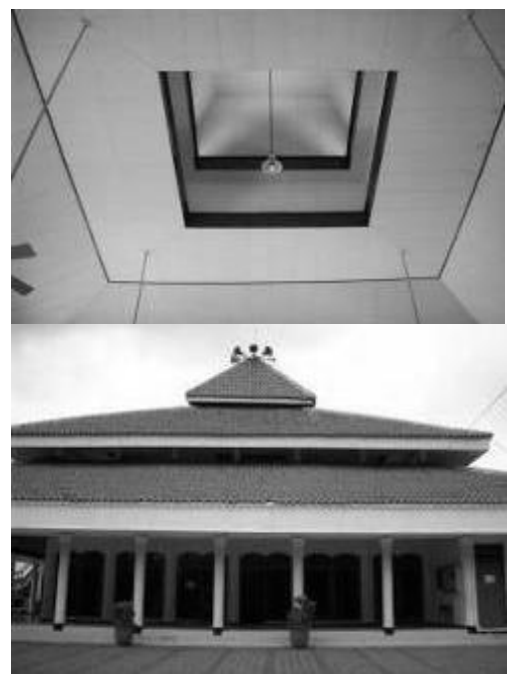

Figure 2. The ceiling (above) and exterior (below) of Masjid Al-Maghfirah

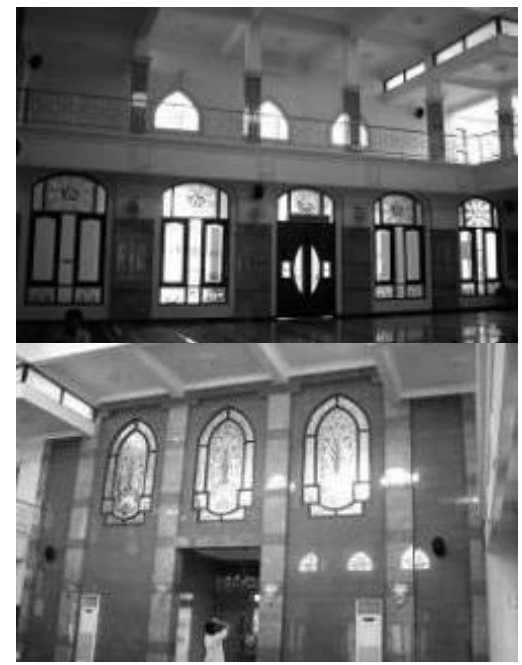

Figure 3. Interior of Masjid Nurul Iman

Meanwhile, Masjid Nurul Iman (Figure 3 - 4) is located at Margorejo Indah Estate, Surabaya. The south and the north side of this mosque is the highest source of noise, while the west side bounds with the residential buildings and the east side is adjacent to the river. This mosque has a square plan form and dome ceiling form. The dimension of this mosque is $15 \times 15 \times 8 \mathrm{~m}^{3}$.

The largest part of this mosque's interior is the reflecting materials, which are marble floor, glass window, brick plester wall, ceramic tile on wall, and plywood doors. There is only $1 / 3$ part of the floor that is covered by carpet. With that kind of composition material, it could be predicted that the mosque might have a bad acoustic quality because the reflected area is bigger then the absorpted area. The area of the opening is $8 \%$ of the wall area. It adds the area of reflected material ${ }^{8}$.

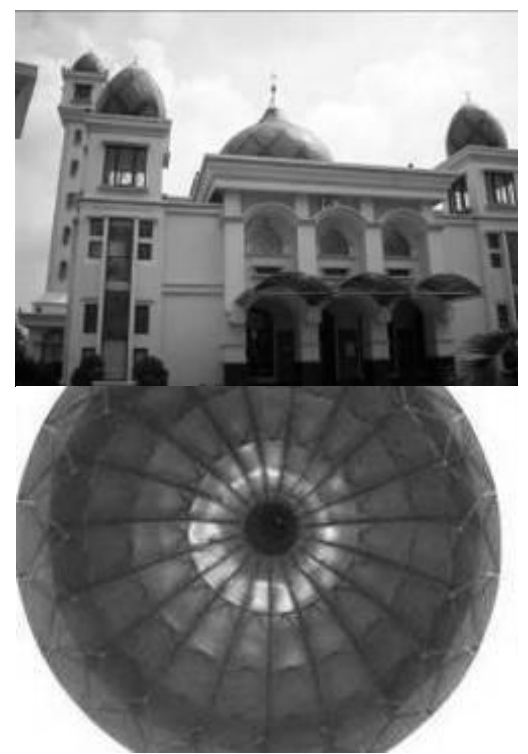

Figure 4. The Exterior and the Ceiling Form of Masjid Nurul Iman

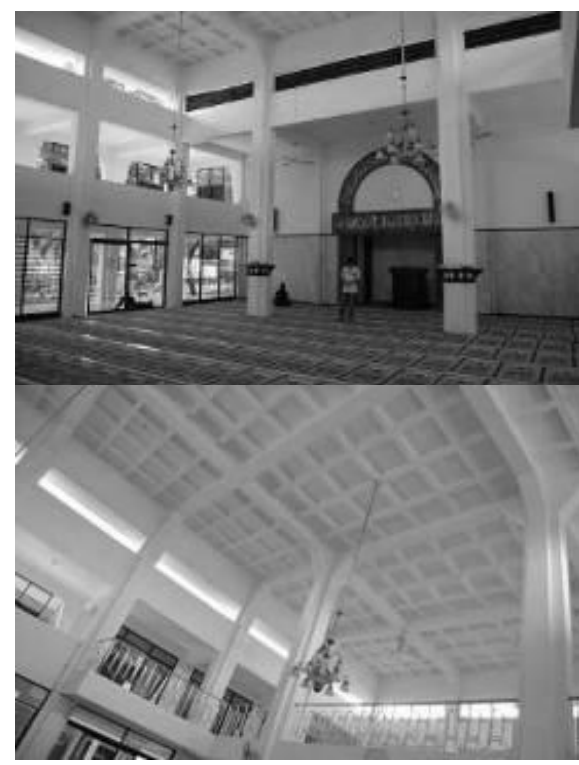

Figure 5. Interior of Masjid Baitussalam 
Masjid Baitussalam (Figure 5) is located at Ketintang Madya Estate Surabaya. The location of this mosque is side by side with Baitussalam Junior High School and the main road that is the highest source of noise. The plan shape of this mosque is rectangle with the long side parallel to kibla. The ceiling shape is flat. The dimension of the mosque is $12,8 \times 21,6 \times 8 \mathrm{~m}^{3}$. The material of this mosque is a reflecting material, which are glass window, glass door, brick plester wall, and ceramic tile on the wall. All of the floor is covered by the carpet, so it could reduce the reflecting area. The opening area is $20 \%$ wall area. It also could reduce the reflecting area.

From the field measurement that has been done in those three mosques, none of them has a standard RT value for the speech room without reinforcement system. All of the result is above the standart. So, the medium size of mosques which should not need a reinforcement system, are forced to use one to conquer the bad acoustic quality. This is an example of energy ineficiency in these buildings.

The average of RT value of Masjid Nurul Iman is 3,38 second, Masjid al-Maghfirah is 2,231 second, and Masjid Baitussalam is 2,636 second. Meanwhile, the standard value of RT for the mosque is between 0,9 - 1,2 second. So, the RT value of the measured mosques are way up above the standard. To create a room with a good quality of acoustic, the specific strategy is needed in designing mosque.

The simulation with ecotect program has been done before. It compared the acoustic quality of mosque with a different form. The result of the simulation shows that every kind of plan shape might have the standard RT value, but the combination with the ceiling form and opening area also determine this value. The result of the simulation could become the basis of the improvement of the acoustic quality on those mosques.

\section{The Strategy to Increase the Room Acoustic Quality of Masjid Al-Maghfirah}

The form of the mosque which has an optimal acoustic value according to the simulation result is the mosque with a square shape plan, flat shape ceiling, and $26 \%$ of opening. From the result, it could be predicted that the factors which cause the bad value of acoustic quality in Masjid Al-Maghfirah are the crown form ceiling and the reflecting materials. Crown ceiling will cause the RT value increase because the crown planes would make the sound reflected inside the ceiling. The opening area also affect the acoustic room because the wide of the opening represent the wide of absorption area.

From the opening area, it could be counted that it needs $3 \%$ more of the opening area to make the absoprtion area for a better acoustic value. This difference is still acceptable because it was not too big. So, the biggest problem here is the crown ceiling. There are some ways to handle this problem. One of them is by changing the ceiling material with the absorbing material so that the sound will not be reflected inside the ceiling. Another way is adding the flat surface below the ceiling. This surface could direct the sound to reflect on the carpet or the people below. This would help the absorption, and this strategy could anticipate two things, first is reducing the RT value and second is fixing the sound distribution to the whole jamaah. However, if both ways could not be done, then adding the opening area could also be another option. The opening area or the absorption area should be widen into $57 \%$ of the wall area. This strategy could reduce the RT value but could not fix the sound distribution.

\section{The Strategy to Increase the Room Acoustic Quality of Masjid Nurul Iman}

The biggest acoustic problem in Masjid Nurul Iman is the reflecting area and the dome ceiling that has caused the very huge reflected sound, especially inside the dome and then run straight to the center below the dome. That path of sound could raise RT value far above the standard and therefore cause a bad sound distribution.

The wide area of the reflection in Masjid Nurul Iman can be seen from the area covered by the carpet which only $1 / 3$ area of the floor. Besides, the opening area was only $8 \%$ of the wall area. One thing could be done to decrease the RT value was by adding the absorbing area, such as covering the whole floor by carpet and covering the wall with an absorbing material. This area should be $26 \%$ of the wall area. If the area is too wide, it would decrease the RT value too low. Those absorbing materials could be replaced by the openings. The changing of the dome material by the absorbing material could also decrease the RT value.

To handle the sound distribution below the dome is by giving it a flat plane below it. The arrangement of these planes is just the same with the crown ceiling, which will direct the imam's voice straight to the jamaah according to the theory of the path of sound inside the enclosed room. This strategy could distribute the sound to the whole room and also could reduce the RT value as well. If these thing were done, then the changing of the ceiling material should not be done. Because if all of the strategies were done, then the RT value will decrease too far below the standard. This is not considered as a good condition, because the sound will dissappear too quick before it can be heard by the jamaah. 
The Strategy to Increase the Room Acoustic Quality of Masjid Baitussalam

Masjid Baitussalam has an acoustic problem which is caused by its plan shape. It is rectangle with the long side parallel to kibla. The problem is the bad sound distribution and the high RT value.

The strategy to fix this problem is by adding the opening area or the absorption surfaces into $26 \%$ of wall area. To handel the sound distribution, the reflector could be used and arranged to direct the sound to the whole jamaah. This reflector could be arranged in the ceiling or walls.

\section{Conclusion}

There are lots of strategies that can be done in facing the bad acoustic quality of the mosque. All of the strategy is to fix the high value of RT and the bad sound distribution in the mosque which is supposed to use no reinforcement system.

One thing to do is by adding the reflector that would direct the sound from imam to the whole jamaah. The other thing to do is by adding the absorption area on the floor and walls to reduce the RT value. The absorption area of walls could also be replaced by the opening.

Some of those strategies is according to the result of the previous research, "The Influence of the Mosques' Form to the Room Acoustic Quality"8. From the strategies mentioned above, some simulations are still needed to determine the exact RT value after implementing those strategies.

\section{References}

1,2 M. Faqih, J. Prijotomo, Murtijas. 1991. Tipologi Arsitektur Masjid Tanpa Arsitek di Surabaya. Surabaya: Lemlit ITS

3,5 CE. Mediastika. 2005. Akustika Bangunan Prinsip-Prinsip dan Penerapannya di Indonesia. Jakarta: Erlangga

4,6 SV. Szokolay. 2004. Introduction to Architectural Science the Basis of Sustainable Design. Oxford: Architecturall Press

7 S. Murtiyoso. 2000. "Masjid Agung Kasepuhan: Prototype Masjid Jawa”, dalam Masjid2000 CD ROM. Bandung: ITB

8 LL. Doelle. 1986. Akustik Lingkungan. Jakarta: Erlangga 